\title{
Türkiye'de Destinasyon Konusunda Yayınlanmış Lisansüstü Tezlerin Bibliyometrik İncelenmesine Yönelik Bir Araştırma
}

\author{
Aydın ÜNAL* \\ Sinan Baran BAYAR*
}

\begin{abstract}
$\ddot{\mathbf{O} z}$
Bu çalışmada Türkiye'de destinasyon alanında yapılmış akademik çalışmaların süreç içerisindeki geli-şimlerinin incelenmesi ve alan yazına katkı sunmak amacıyla ilgili konu başlığında yayınlanmış lisan-süstü tezlerin bibliyometrik analizlerinin yapılması amaçlanmaktadır. Bu kapsamda Yükseköğretim Kurulu Başkanlığı Ulusal Tez Merkezi Veri Tabanı'nda (YÖKTEZ) 1996-31 Aralık 2019 tarihleri arasın-da "destinasyon” konu başlığında yayınlanmış lisansüstü tezler (844 adet) bibliyometrik olarak analiz edilmiştir. Bilimsel araştırmalarda bibliyometrik analiz; belirli bir alanda, belirli bir dönemde ve belirli bir bölgede kişiler ya da kurumlar tarafından üretilmiş yayınların ve bu yayınlar arasındaki ilişkilerin sayı-sal olarak incelenmesine dayanmaktadır. Yapılan analizler neticesinde; YÖKTEZ'de yer alan "destinasyon" konulu lisansüstü tezlerin en çok 2019 yılında (\%23), yüksek lisans düzeyinde (\%72), turizm konu başlığında (\%61), profesör unvanı taşıyan danışmanlar eşliğinde (\%37), Gazi (\%9) ve Akdeniz (\%8) üniversitelerinde, sosyal bilimler enstitülerinde (\%89), turizm işletmeciliği anabilim dalında (\%60), Türkçe dilinde (\%94), 101-200 sayfa aralığında (\%64), nicel yöntemlerle (\%59), geleneksel anket tekniği kullanı-larak (\%57), 301 ve üzeri örneklem hacmine uygulanarak (\%49) ve 101-150 kaynakla (\%26) hazırlan-dıkları tespit edilmiştir. Araştırma sonucunda yayınlanan tezlerin yıllık bazda her yıl sayılarının arttığı, ancak doktora düzeyinde, Türkçe dışında dillerde ve geleneksel anket veri toplama yöntemi dışında yöntemlerle hazırlanmış tezlerin sınırlı düzeyde kaldıkları belirlenmiştir.
\end{abstract}

Anahtar kelimeler: Konaklama İşletmeleri, Turizm Gazetesi, İș İlanları.

\section{A Research on Bibliometric Analysis of Graduate Thesis Published in Turkey About Destinations}

\begin{abstract}
In this study, it is aimed to investigate the development process of the academic work done in the field of destination in Turkey and to do a bibliometric analysis of the graduate theses published on the related topic in order to contribute to the related literature. In this context, graduate theses (844 theses) published on the subject of "destination" between 1996-31 December 2019 and opened to public access on the Higher Education Council National Thesis Center Database (YÖKTEZ) were analyzed bibliometrically. Bibliometric analysis in scientific research is based on a numerical analysis of the publications produced by individuals or institutions in a particular area, in a given period and in a particular region, and the relations between these publications. As a result of the analyzes; it was found that the graduate theses published on the subject of "destination" were most published (23\%) in 2019 and most of them (72\%) were master's theses. It was also found that the analyzed theses were published most on the topic title of tourism (61\%) and were most accompanied by professors (37\%). In addition, it was found that most of them were prepared at the universities of Gazi (9\%) and Akdeniz (8\%), at the social sciences institutes $(89 \%)$, at the department of tourism management $(60 \%)$ and were published in Turkish (94\%). Finally, it was found that most of the analyzed theses had number of pages between the range of 101 and $200(64 \%)$; were prepared using quantitative methods (59\%) and traditional questionnaire technique (57\%); were applied to 301 and above sample size (49\%) and were written using 101-150 sources (26\%). As a result of the research, it has been determined that the number of theses published annually increases on a yearly basis, but theses prepared at the level of doctorate, in languages other than Turkish, and methods other than the traditional survey data collection method remain limited.
\end{abstract}

Keywords: Destination, Tourism, Graduate Thesis, Bibliometric Analysis, YOKTEZ.

Received/Geliș: 17.01 .2020

Accepted/Kabul: 04.06.2020

Bu esere ilişkin veri toplama süreci 15 Aralık 31 Aralık 2019 tarihleri arasında tamamlanmış olup Yükseköğretim Kuru-lu Başkanlığı TR DİZiN Etik Kurul Kriterleri 1 Ocak 2020 tarihinde dergilerce ilan edilmiştir. Bu kapsamda Kırklareli Üniversitesi Bilimsel Araştırmalar ve Yayın Etiği Kurulu'na yaptığımız 13 Mart 2020 tarihli Etik Kurul Onay Belgesi başvurumuz araştırmanın veri toplama sürecinin tamamlanması ve ilgili kriterlerin 2020 yılı ve sonrasında veri toplama süreçleri yürütülecek çalıșmalar için gerekli olduğu gerekçe gösterilerek tarafımıza verilmemiştir.

* Dr. Öğretim Üyesi, Kırklareli Üniversitesi, Pınarhisar Meslek Yüksekokulu, Pınarhisar/Kırklareli/Türkiye. aydin.unal@klu.edu.tr; 054385380 69; D/0000-0002-6377-8587

* Yüksek Lisans Öğrencisi, Kırklareli Üniversitesi, Sosyal Bilimler Enstitüsü, Turizm İşletmeciliği ABD/Kırklareli/Türkiye. sinanbbayar@gmail.com, D/0000-0002-3039-3162

(Makale türü: Araştırma makalesi) 


\section{Giriş}

Turizm; sürekli gelişen, dünya ticareti içerisindeki payını ve hacmini arttıran ekonomik bir sektördür. Turistik destinasyonlar da turizm sektörünün önemli bileşenlerindendirler ve tek başlarına değerlendirilmeleri, planlanmaları, yönetilmeleri ve pazarlanmaları gerekmektedir. Destinasyon kavramı; turistlerin isteklerini ve gereksinimlerini karşıladıkları, önemli turistik etkinliklere, çekiciliklere sahip ve turistlere deneyim imkânı sunan bölgeler olarak tanımlanabilir (Swarbrooke, 1995; Atay, 2003). Dünya ve Türkiye ölçeğinde ise turistlerin yenilik, farkl11ık, macera ve diğer arayışları yeni destinasyonların keşfedilmesine veya mevcut destinasyonların ön plana çıkmasına katkı sağlamaktadır. Bu gelişmeler hem sektörel hem de akademik açıdan yeni araştırma konularının ortaya çıkmasını katkı sağlamaktadır (Aydın ve Aksöz, 2019). Destinasyonlar hakkında; sektörel veya akademik teorik veya pratik bilgilerin ve istatistiki verilerin tutulması, incelenmesi ve yorumlanması farklı disiplinler açısından da (özellikle zaman içerisindeki eğilimlerin öğrenilmesi ve nesnel bulgulara ve sonuçlara ulaşılması, gibi) önem arz etmektedir (Üsdiken ve Pasadeos, 1992; Kozak, 2001; Crossan ve Apaydın, 2010; Çiçek ve Kozak, 2012; Nergiz Güçlü, 2014; Tayfun ve diğer., 2016). Bu sürecin genelinde ve akademik bilgilerin üretilmesinde ise üniversiteler ve lisansüstü eğitim programları önemli bir yere sahiptirler (Alkan, 2014; Beşel, 2017). Yüksek lisans ve doktora programları düzeyinde verilen lisansüstü eğitimde uzman ve akademisyen yetiştirmenin yanı sıra öğrencilere bilimsel bilgiye erişme, bilgiyi değerlendirme ve yorumlama becerisi kazandırma ve sentez yetilerini güçlendirme amaçlanmaktadır (Olalı, 1984; Nergiz Güçlü, 2014; İnce ve diğer., 2017). Lisansüstü eğitim süreci sonunda sunulan tez çalışmaları öğrencilerin, üniversitelerin ve dolaylı olarak ta ülkelerin uluslararası mecralarda tanınırlığına katkı sağlamaktadırlar (Tayfun ve diğer., 2018). Ayrıca bir kavramın veya disiplinin gösterdiği gelişimi incelemek açısından da lisansüstü tezler kaynak oluşturmaktadırlar. Lisansüstü tezlerin incelenmesinde ise bibliyometrik analiz öne çıkan yöntemlerdendir. Bibliyometrik analiz; bir alanın bilimsel gelişim sürecini matematiksel ve istatistiksel yöntemlerle analiz eden, bilimsel bilginin ve bir ürünün özelliklerini kimin tarafından, nerede, nasıl ve hangi açıdan ortaya konulduğunu belirlemeye imkân veren bir araştırma yöntemidir (Yozgat ve Kartaltepe, 2009; Güzeller ve Çeliker, 2017; Sanchez, 2017). Bibliyometrik analiz ile bir kavram ve disiplin hakkındaki çalışmaların nicel hale getirilmesi, çalışmaların tarihsel gelişiminin ve seyrinin ortaya konması mümkün hale gelmektedir (Alkan, 2014; Arıca, 2014; Şahin ve diğer., 2018; Tayfun ve diğer., 2018). Bu çalışmada da Türkiye’de destinasyon konu başlığında yapılmış akademik çalışmaların süreç içerisindeki gelişimlerinin incelenmesi ve alan yazına katkı sunmak amacıyla ilgili konuda yayınlanmış lisansüstü tezlerin değişik parametreler çerçevesinde bibliyometrik olarak analiz edilmesi amaçlanmaktadır. 


\section{İlgili Araştırmalar}

Türkiye'de turizm araştırmalarını inceleyen ilk yayın 1933 yılında Reşit Saffet ATABİNEN tarafindan Türkiye Turing ve Otomobil Kulübü Neşriyatı'nda 12-18 Adalet Han, Galata/İstanbul adıyla yayınlanmıştır (Şardağ, 2016). Geçen süre içerisinde turizmin farklı konularını inceleyen çeşitli araştırmalar özellikle 1990'lı yıllarla birlikte hızlı ve yoğun bir biçimde yayınlanmaya başlamıştır. Çoğunluğunda bibliyometrik analiz yönteminden yararlanılarak yayınlanan bu çalışmaların bazıları aşağıda özetlenmiştir.

Turizm konu başlı̆̆ında; Nergiz Güçlü (2014) 1990-2013 yılları arasında Türkiye'de yayınlanmış 2348 lisansüstü tezi; Turan (2014) 1984-2013 yılları arasında Türkiye'de yayınlanmış 1670 lisansüstü tezi ve Tekin (2016) 1985-2016 yılları arasında Türkiye'de yayınlanmış 367 lisansüstü tezi farklı parametreler çerçevesinde bibliyometrik olarak analiz etmişlerdir.

Yiyecek-içecek ve gastronomi konu başlığında; Aydın (2014) 1988-2013 yılları arasında Türkiye'de yayınlanmış 179 lisansüstü tezi; Sünnetçioğlu ve diğer. (2017) Türkiye'de yayınlanmış 33 lisansüstü tezi; Tayfun ve diğer. (2018) 1990-2018 yılları arasında Türkiye’de yayınlanmış 164 lisansüstü tezi ve Ayaz ve Türkmen (2018) 1999-2017 yılları arasında Türkiye'de yayınlanmış 45 lisansüstü tezi farklı kriterler kapsamında analiz etmişlerdir.

Ayrıca Arıca (2014) 1988-2013 yılları arasında Türkiye'de yayınlanmış 220 seyahat ve turizm konulu lisansüstü tezi; Şahin ve Acun (2015) 1989-2015 yılları arasında Türkiye'de yayınlanmış 38 rehberlik ve turizm konulu lisansüstü tezi; Toksöz ve Birdir (2016) 2006-2015 yılları arasında Türkiye' de yayınlanmış 84 kültürel miras ve turizm konulu lisansüstü tezi; Şardağ (2016) Türkiye'de yayınlanmış 103 coğrafya ve turizm konulu lisansüstü tezi; Alımanoğlu (2017) 2003-2016 yılları arasında Türkiye'de yayınlanmış 20 kırsal turizm konulu lisansüstü tezi; İnce ve diğer. (2017) 1990-2016 yılları arasında Türkiye'de yayınlanmış 177 turizm pazarlaması konulu lisansüstü tezi; Demirbulat Güdü ve Dinç Tetik (2017) 1987-2015 y1lları arasında Türkiye'de yayınlanmış 62 sürdürülebilir turizm konulu lisansüstü tezi ve Akyol (2017) Türkiye'de yayınlanmış 46 turizm eğitimi konulu lisansüstü tezi farklı parametreler çerçevesinde analiz etmişlerdir.

Turizm ve destinasyon konu başlığında ise sadece Aydın ve Aksöz'ün (2019) 2003-2018 yılları arasında Türkiye'de yayınlanmış 236 lisansüstü tezi bibliyometrik olarak inceledikleri çalışmalarına ulaşılmıştır. Çalışmada ilgili tezler; yıl, tür, enstitü, anabilim dalı, üniversite, konu, yöntem, örnekleme hacmi, sayfa sayısı ve danışman unvanı göre dağılımları açısından kategorize edilmişlerdir. 


\section{Yöntem}

\section{Araştırmanın Amacı}

Çalışmada Yükseköğretim Kurulu Başkanlığı Ulusal Tez Merkezi veri tabanında (YÖKTEZ) 1996-31 Aralık 2019 tarihleri arasında "destinasyon” konu başlığında yayınlanmış lisansüstü tezlerin (844 adet) bibliyometrik olarak incelenmesi ve belirli başliklar altında (tezlerin; yıllara göre dağılımı, türü, konusu, danışman unvanları, üniversitesi, enstitüsü, ana bilim dalı, dili, sayfa sayısı, yöntemi, veri toplama yöntemi, örneklemi ve kullanılan kaynak sayısı) kategorize edilmesi amaçlanmaktadır.

\section{Araştırmanın Kapsamı}

Araştırma amacı doğrultusunda ilgili literatür incelenmiştir (Akmeşe ve diğer., 2018; Akyol, 2017; Arıca, 2014; Aydın ve Aksöz, 2019; Demirbulat Güdü ve Dinç Tetik, 2017; İnce ve diğer., 2017; Şahin ve diğer., 2018; Şardă̆, 2016; Tayfun ve diğer., 2016; Toksöz ve Birdir, 2016; Tayfun ve diğer., 2018). Yapılan çalışmaların turizmin spesifik bir konusu üzerinden (örneğin; sürdürülebilir turizm, seyahat işletmeciliği, turizm coğrafyası, gastronomi, vb.) yürütüldüğü belirlenmiştir. Bu çalışmada da YÖKTEZ veri tabanında "destinasyon" konu başlığında yer alan 844 adet çalışma incelenmiştir.

\section{Araştırmada Veri Toplama Yöntemi ve Verilerin Analizi}

Bu çalışmada YÖKTEZ veri tabanında 1996-31 Aralık 2019 tarihi itibariyle "destinasyon" konu başlığında tespit edilmiş olan toplam 844 adet lisansüstü tez çalışması bibliyometrik olarak analiz edilmiştir. Akademik çalışmalarda bibliyometrik analiz; belirli bir alanda, belirli bir dönemde belirli bir bölgede kişiler ya da kurumlar tarafından üretilmiş yayınların ve bu yayınlar arasındaki ilişkilerin sayısal olarak incelenmesine dayanmaktadır (Al ve diğer., 2010; Cahit Arf Bilgi Merkezi, 2019).

\section{Araştırmanın Evreni ve Örneklemi}

Sosyal bilimlerde araştırmacıların araştırma sonuçlarını genellemek istediği birimlerin bütünü ana kütle (evren) ve belirli bir ana kütleyi temsil yeterliliğine sahip olduğu kabul edilen, belirli bir evrenden belli kurallara göre seçilmiş ve bir bütünün parçası olan daha küçük kütle ise örneklem olarak tanımlanmaktadır (Karasar, 2002). Bu çalışmada ana kütleyi Türkiye'de yayınlanmış turizm alanındaki tüm lisansüstü tezler; araştırma örneklemini ise "destinasyon" konu başlığında 1996-31 Aralık 2019 tarihleri arasında yayınlanmış tüm lisansüstü tezler oluşturmaktadır. Bu çalışmada örneklemi oluşturan 844 lisansüstü tezin tümü 15 Aralık-31 Aralık 2019 döneminde "tez.yok.gov.tr" web sitesinde erişilebilen içerikleri açısından değerlendirilmişlerdir. 


\section{Bulgular}

Araştırmaya dâhil edilen lisansüstü tezlerin yıllara göre dağılımlarına bakıldığında (Tablo 1) tezlerin çoğunluğunun; 2019 (\%23,2), 2018 (\%14,2), 2017 (\%11,7), 2016 (\%9,5), $2015(\% 8,4)$, $2014(\% 6,6), 2013(\% 5,6), 2010(\% 4,5)$ ve $2012(\% 3,4)$ yıllarında yayınlandığ tespit edilmiştir. Ayrıca ilgili konu başlığında 1996, 1997, 2000, 2001, 2002, 2003, 2004, 2005, 2006, 2007, 2008, 2009 ve 2011 yıllarında toplam \%23,1 oranında lisansüstü tez yayınlandığı ve 1998 ve 1999 yıllarında ilgili konu başlığında lisansüstü tez çalışması yayınlanmadığı tespit edilmiştir.

Tablo 1. Lisansüstü Tezlerin Yıllara Göre Dağılımı ile İlgili Genel Bilgiler

\begin{tabular}{cccccc}
\hline Yayın Yılı & $\begin{array}{c}\text { Sayı } \\
\text { (n) }\end{array}$ & Yüzde (\%) & Yayın Yılı & Sayı (n) & Yüzde (\%) \\
\hline 1996 & 1 &, 1 & 2009 & 12 & 1,4 \\
\hline 1997 & 2 &, 2 & 2010 & 38 & 4,5 \\
\hline 1998 & 0 & 0 & 2011 & 25 & 3,0 \\
\hline 1999 & 0 & 0 & 2012 & 29 & 3,4 \\
\hline 2000 & 1 &, 1 & 2013 & 47 & 5,6 \\
\hline 2001 & 2 &, 2 & 2014 & 56 & 6,6 \\
\hline 2002 & 6 &, 7 & 2015 & 71 & 8,4 \\
\hline 2003 & 4 &, 5 & 2016 & 80 & 9,5 \\
\hline 2004 & 10 & 1,2 & 2017 & 99 & 11,7 \\
\hline 2005 & 6 &, 7 & 2018 & 120 & 14,2 \\
\hline 2006 & 9 & 1,1 & 2019 & 196 & 23,2 \\
\hline 2007 & 14 & 2,3 & Toplam & $\mathbf{8 4 4}$ & $\mathbf{1 0 0}$ \\
\hline 2008 & 11 & 1,3 & & & \\
\hline
\end{tabular}

Araştırmaya dâhil edilen lisansüstü tezlerin türlerine göre dağılım verileri ile ilgili temel bulgular Tablo 2'de özetlenmiştir. Araştırmaya dâhil edilen lisansüstü tezlerin \%72'sinin yüksek lisans ve \%28'inin doktora düzeyinde hazırlandığı belirlenmiştir.

Tablo 2. Lisansüstü Tezlerin Türlerine Göre Dağılımı ile İlgili Genel Bilgiler

\begin{tabular}{ccc}
\hline Tez Türü & Sayı (n) & Yüzde (\%) \\
\hline Doktora & 236 & 28,0 \\
\hline Yüksek Lisans & 608 & 72,0 \\
\hline Toplam & $\mathbf{8 4 4}$ & $\mathbf{1 0 0}$
\end{tabular}

Araştırmaya dâhil edilen lisansüstü tezlerin konularına göre dağılım verileri ile ilgili temel bulgular Tablo 3'te özetlenmiştir. Araştırmaya dâhil edilen lisansüstü tezlerin \%61,4'nün turizm, \%22,1'inin iktisadi ve idari bilimler, \%3,3'ünün iletişim, \%3'ünün mimarlık, \%2,5'inin coğrafya, \%1,9'unun ekonomi, \%1,5'inin mühendislik ve \%1,1'inin spor bilimleri konu başlığında hazırlandığı belirlenmiştir. Ayrıca ziraat, biyoloji, eğitim bilimleri, sağlık bilimleri ve islami bilimler konu başlığında $(\% 4,7)$ lisansüstü tezlerinde yayınlandığı tespit edilmiştir. 
Aydın ÜNAL, Sinan Baran BAYAR

Türkiye'de Destinasyon Konusunda Yayınlanmış Lisansüstü Tezlerin Bibliyometrik İncelenmesine Yönelik Bir Araştırma

Tablo 3. Lisansüstü Tezlerin Konularına Göre Dağılımı ile İlgili Genel Bilgiler

\begin{tabular}{cccccc}
\hline Tez Konusu & $\begin{array}{c}\text { Sayı } \\
(\mathbf{n})\end{array}$ & Yüzde (\%) & Tez Konusu & Sayı (n) & Yüzde (\%) \\
\hline Turizm & 518 & 61,4 & Sosyoloji & 7 &, 9 \\
\hline İ.̇̇.B.F. & 187 & 22,1 & $\begin{array}{c}\text { Eğitim } \\
\text { Bilimleri }\end{array}$ & 5 &, 6 \\
\hline İletişim & 28 & 3,3 & Biyoloji & 5 &, 6 \\
\hline Mimarlı & 25 & 3,0 & $\begin{array}{c}\text { Sağlık } \\
\text { Bilimleri }\end{array}$ & 5 &, 6 \\
\hline Coğrafya & 21 & 2,5 & Ziraat & 3 &, 4 \\
\hline Ekonomi & 16 & 1,9 & $\begin{array}{c}\text { İslami } \\
\text { Bilimler }\end{array}$ & 1 \\
\hline Mühendislik & 13 & 1,5 & Toplam & $\mathbf{8 4 4}$ & $\mathbf{1 0 0}$ \\
\hline Spor Bilimleri & 9 & 1,1 & & \\
\hline Araștırmaya & & & & \\
\hline
\end{tabular}

Araştırmaya dâhil edilen lisansüstü tezlerin danışman unvanlarına göre dağılım verileri

ile ilgili temel bulgular Tablo 4'te özetlenmiştir. Araştırmaya dâhil edilen lisansüstü tezlerin \%37,2'sinin profesör, \%34,5'inin doçent ve \%28,3'ünün doktor öğretim üyesi unvanı taşıyan öğretim üyeleri tarafından danışmanlıklarının yürütüldüğü belirlenmiştir.

Tablo 4. Lisansüstü Tezlerin Danışman Unvanlarına Göre Dağılımı ile İlgili Genel Bilgiler

\begin{tabular}{ccc}
\hline Danışman Unvanı & Sayı (n) & Yüzde (\%) \\
\hline Prof. Dr. & 314 & 37,2 \\
\hline Doç. Dr. & 291 & 34,5 \\
\hline Dr. Öğretim Üyesi & 239 & 28,3 \\
\hline Toplam & $\mathbf{8 4 4}$ & $\mathbf{1 0 0}$
\end{tabular}

Araştırmaya dâhil edilen lisansüstü tezlerin üniversitelere göre dağılım verileri ile ilgili temel bulgular Tablo 5'te özetlenmiştir. Araştırmaya dâhil edilen lisansüstü tezlerin \%8,8'nin Gazi, \%8,1'inin Akdeniz, \%6,2'sinin Dokuz Eylül, \%5,6'sının Balıkesir, \%4,6'sının İstanbul, \%3,8'inin Çanakkale 18 Mart, \%3,6'sının Muğla Sitkı Koçman, \%3’ünün Sakarya, \%2,7'sinin Adnan Menderes, \%2,6’sının Selçuk ve \%2,6'sının Nevşehir Hacı Bektaş Veli üniversitelerinde hazırlandığı (toplam \%51,6) ve geriye kalan lisansüstü tezlerin \%48,4’ünün ise 81 farklı devlet, vakıf ve özel üniversitelerinde hazırlandıkları belirlenmiştir.

Tablo 5. Lisansüstü Tezlerin Üniversitelere Göre Dağılımı ile İlgili Genel Bilgiler

\begin{tabular}{cccccc}
\hline Üniversite & $\begin{array}{c}\text { Sayı } \\
(\mathbf{n})\end{array}$ & Yüzde (\%) & Üniversite & Sayı (n) & $\begin{array}{c}\text { Yüzde } \\
(\%)\end{array}$ \\
\hline Gazi Ü. & 74 & 8,8 & Hacettepe Ü. & 3 &, 4 \\
\hline Akdeniz Ü. & 68 & 8,1 & Pamukkale Ü. & 3 &, 4 \\
\hline Dokuz Eylül Ü. & 52 & 6,2 & Harran Ü. & 3 &, 4 \\
\hline Balıkesir Ü. & 47 & 5,6 & İbrahim Çeçen Ü. & 3 &, 4 \\
\hline İstanbul Ü. & 39 & 4,6 & Kocaeli Ü. & 3 &, 4 \\
\hline Çanakkale 18 Mart Ü. & 32 & 3,8 & Yeditepe Ü. & 3 &, 4 \\
\hline Muğla Sitkı Koçman Ü. & 30 & 3,6 & İstanbul Arel Ü. & 3 &, 4 \\
\hline Anadolu Ü. & 26 & 3,1 & Hacı Bay. Veli Ü. & 2 &, 2 \\
\hline Sakarya Ü. & 25 & 3,0 & Galatasaray Ü. & 2 &, 2 \\
\hline
\end{tabular}




\begin{tabular}{|c|c|c|c|c|c|}
\hline Üniversite & $\begin{array}{c}\text { Sayl } \\
\text { (n) }\end{array}$ & Yüzde (\%) & Üniversite & Sayı (n) & $\begin{array}{c}\text { Yüzde } \\
(\%)\end{array}$ \\
\hline Adnan Menderes Ü. & 23 & 2,7 & $\begin{array}{l}\text { Van Yüzün. Yıl } \\
\text { Ü. }\end{array}$ & 2 & ,2 \\
\hline Selçuk Ü. & 22 & 2,6 & $\begin{array}{l}\text { Alaed. Keykubat } \\
\text { Ü. }\end{array}$ & 2 & ,2 \\
\hline Nev. Hacı Bektaş Veli Ü. & 22 & 2,6 & Giresun Ü. & 2 & 2 \\
\hline Mersin Ü. & 20 & 2,4 & İstanbul Kültür Ü. & 2 & , 2 \\
\hline Afyon Kocatepe Ü. & 15 & 1,8 & Maltepe Ü. & 2 & 2 \\
\hline Atatürk Ü. & 15 & 1,8 & Gebze Teknik Ü. & 2 & 2 \\
\hline Gaziantep Ü. & 13 & 1,5 & Bülent Ecevit Ü. & 2 & , 2 \\
\hline Erciyes Ü. & 13 & 1,5 & $\begin{array}{l}\text { TOBB Eko. Tek. } \\
\text { Ü. }\end{array}$ & 2 & ,2 \\
\hline Karabük Ü. & 12 & 1,4 & Fatih Ü. & 2 & 2 \\
\hline Yaşar Ü. & 12 & 1,4 & Çukurova Ü. & 2 & ,2 \\
\hline İzmir Kâtip Çelebi Ü. & 12 & 1,4 & Başkent Ü. & 2 & 2 \\
\hline Bahçeşehir Ü. & 11 & 1,3 & Doğuş Ü. & 2 & ,2 \\
\hline Eskişehir Osmangazi Ü. & 11 & 1,3 & Haliç Ü. & 2 & ,2 \\
\hline Atılım Ü. & 11 & 3 & Celal Bayar Ü. & 2 & 2 \\
\hline Trakya Ü. & 11 & 1,3 & İst. Medeniyet Ü. & 2 &, 2 \\
\hline Ankara Ü. & 11 & 1,3 & Kafkas Ü. & 2 & ,2 \\
\hline Ankara Ü. & 11 & 1,3 & İstanbul Bilgi Ü. & 2 & ,2 \\
\hline Trakya Ü. & 11 & 1,3 & Sütçü İmam Ü. & 2 & ,2 \\
\hline Süleyman Demirel Ü. & 10 & 1,2 & Çankaya Ü. & 1 & 1 \\
\hline Kastamonu Ü. & 10 & 1,2 & $\begin{array}{l}\text { Siv. Cumhuriyet } \\
\text { Ü. }\end{array}$ & 1 & ,1 \\
\hline Marmara Ü. & 9 & 1,1 & $\begin{array}{l}\text { Adana Bil. Tekn. } \\
\text { Ü. }\end{array}$ & 1 & ,1 \\
\hline Necmettin Erbakan Ü. & 9 & 1,1 & İsken. Teknik Ü. & 1 & , 1 \\
\hline Karadeniz Teknik Ü. & 9 & 1,1 & Bursa Uludağ Ü. & 1 & , 1 \\
\hline Ege Ü. & 9 & 1,1 & Yozgat Bozok Ü. & 1 & , 1 \\
\hline İstanbul Teknik Ü. & 8 & 9 & İstanbul Aydın Ü. & 1 & ,1 \\
\hline İstanbul Ticaret Ü. & 8 & ,9 & Sabanc1 Ü. & 1 & ,1 \\
\hline Batman Ü. & 8 & 9 & $\begin{array}{l}\text { Küt. Dumlupınar } \\
\text { Ü. }\end{array}$ & 1 & ,1 \\
\hline Sakarya Uyg. Bilimler Ü. & 8 & ,9 & Namık Kemal Ü. & 1 &, 1 \\
\hline Mustafa Kemal Ü. & 6 & ,7 & KTO Karatay Ü. & 1 & ,1 \\
\hline Yıldız Teknik Ü. & 6 & ,7 & İzmir Ekonomi Ü. & 1 & ,1 \\
\hline Düzce Ü. & 6 & ,7 & $\begin{array}{l}\text { İstanbul Medipol } \\
\text { Ü. }\end{array}$ & 1 &, 1 \\
\hline Kırklareli Ü. & 6 & ,7 & Binali Yıldırım Ü. & 1 & 1 \\
\hline $\begin{array}{c}\text { Niğde Ömer Halisdemir } \\
\text { U.. }\end{array}$ & 5 & 6 & Sam. 19 Mayıs Ü. & 1 & ,1 \\
\hline Orta Doğu Teknik Ü. & 4 &, 5 & Şeyh Edebali Ü. & 1 &, 1 \\
\hline Boğaziçi Ü. & 4 & 5 & İstanbul Okan Ü. & 1 & 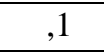 \\
\hline Malatya İnönü Ü. & 4 & 5 & Toplam & 844 & 100 \\
\hline Beykent Ü. & 4 &, 5 & & & \\
\hline
\end{tabular}


Aydın ÜNAL, Sinan Baran BAYAR

Türkiye'de Destinasyon Konusunda Yayınlanmış Lisansüstü Tezlerin Bibliyometrik İncelenmesine Yönelik Bir Araştırma

Araştırmaya dâhil edilen lisansüstü tezlerin enstitülere göre dağılım verileri ile ilgili temel bulgular Tablo 6'da özetlenmiştir. Araştırmaya dâhil edilen lisansüstü tezlerin \%88,6'sının sosyal, \%5'inin fen, \%4,3'ünün eğitim, \%1,8'inin lisansüstü ve \%0,4'ünün sağl1k bilimleri enstitülerinde yayınlandığı belirlenmiştir.

Tablo 6. Lisansüstü Tezlerin Enstitülere Göre Dağılımı ile İlgili Genel Bilgiler

\begin{tabular}{ccc}
\hline Enstitü & Sayı (n) & Yüzde (\%) \\
\hline Sosyal Bilimler Enstitüsü & 748 & 88,6 \\
\hline Fen Bilimleri Enstitüsü & 42 & 5,0 \\
\hline Eğitim Bilimleri Enstitüsü & 36 & 4,3 \\
\hline Lisansüstü Eğitim Enstitüsü & 15 & 1,8 \\
\hline Sağlık Bilimleri Enstitüsü & 3 &, 4 \\
\hline Toplam & $\mathbf{8 4 4}$ & $\mathbf{1 0 0}$ \\
\hline
\end{tabular}

Araştırmaya dâhil edilen lisansüstü tezlerin ana bilim dallarına göre dağılım verileri ile ilgili temel bulgular Tablo 7'de özetlenmiştir. Araştırmaya dâhil edilen lisansüstü tezlerin \%60,3'ünün turizm işletmeciliği, \%18,8'inin iktisadi ve idari bilimler, \%3,7'sinin turizm işletmeciliği eğitimi, \%3,1'inin mimarlık, \%2,9'unun reklamc1lı ve halkla ilişkiler, \%2,1'inin coğrafya ve \%1,8'inin gastronomi ve mutfak sanatları anabilim dallarında hazırlandıkları belirlenmiştir (toplam \%92,7). Lisansüstü tezlerin \%7,3'ünün beden eğitimi ve spor, radyotelevizyon ve sinema, rekreasyon yönetimi, seyahat işletmeciliği, pazarlama, strateji bilimi, yönetim bilişim sistemleri, uluslararası ticaret ve pazarlama, biyoloji, antropoloji, mühendislik, Türk dünyası ve sağlık anabilim dallarında hazırlandıkları tespit edilmiştir.

Tablo 7. Lisansüstü Tezlerin Anabilim Dallarına Göre Dağılımı ile İlgili Genel Bilgiler

\begin{tabular}{ccc}
\hline Anabilim Dalı & Sayı (n) & Yüzde (\%) \\
\hline Turizm İșletmeciliği & 509 & 60,3 \\
\hline İ.̇.B.F. & 158 & 18,8 \\
\hline Murizm İşletmeciliği Ĕ̆itimi & 31 & 3,7 \\
\hline Mimarlık & 26 & 3,1 \\
\hline Reklamcılık ve Halkla İlişkiler & 24 & 2,9 \\
\hline Coğrafya & 18 & 2,1 \\
\hline Gastronomi ve Mutfak Sanatları & 15 & 1,8 \\
\hline Rekreasyon Yönetimi & 11 & 1,3 \\
\hline Mühendislik & 11 & 1,3 \\
\hline Seyahat İşletmeciliği & 10 & 1,2 \\
\hline Uluslararası Ticaret ve Pazarlama & 5 &, 6 \\
\hline Sağlı & 4 &, 5 \\
\hline Antropoloji & 3 &, 4 \\
\hline Radyo, Televizyon ve Sinema & 2 &, 2 \\
\hline Pazarlama & 2 &, 2 \\
\hline Strateji Bilimi & 2 &, 2 \\
\hline Yönetim Bilişim Sistemleri & 2 &, 2 \\
\hline Beden Eğitimi ve Spor & 1 &, 1 \\
\hline Biyoloji & 1 &, 1 \\
\hline Türk Dünyası & 1 &, 1 \\
\hline Tez Erişim İzni Yok & 8 & $\mathbf{1 0 0}$ \\
\hline Toplam & $\mathbf{8 4 4}$ & \\
\hline
\end{tabular}


Araştırmaya dâhil edilen lisansüstü tezlerin dillerine göre dağılım verileri ile ilgili temel bulgular Tablo 8'de özetlenmiştir. Araştırmaya dâhil edilen lisansüstü tezlerin \%93,5'inin Türkçe ve \%6,5'inin İngilizce dillerinde hazırlandıkları belirlenmiştir.

Tablo 8. Lisansüstü Tezlerin Dillerine Göre Dağılımı ile İlgili Genel Bilgiler

\begin{tabular}{ccc}
\hline Dili & Sayı (n) & Yüzde (\%) \\
\hline Türkçe & 789 & 93,5 \\
\hline İngilizce & 55 & 6,5 \\
\hline Toplam & $\mathbf{8 4 4}$ & $\mathbf{1 0 0}$
\end{tabular}

Araştırmaya dâhil edilen lisansüstü tezlerin sayfa sayısı aralıklarına göre dağılım verileri ile ilgili temel bulgular Tablo 9'da özetlenmiştir. Araştırmaya dâhil edilen lisansüstü tezlerin \%63,5'inin 101-200, \%17,7'sinin 201-300, \%12,9'unun 0-100 ve \%5,9'unun 301 ve daha çok sayfadan oluştukları belirlenmiştir.

Tablo 9. Lisansüstü Tezlerin Sayfa Sayısı Aralıklarına Göre Dağılımı ile İlgili Genel Bilgiler

\begin{tabular}{ccc}
\hline Sayfa Aralı̆̆ı & Sayı (n) & Yüzde (\%) \\
\hline 0-100 Sayfa Arası & 109 & 12,9 \\
\hline 101-200 Sayfa Arası & 536 & 63,5 \\
\hline 201-300 Sayfa Arası & 149 & 17,7 \\
\hline 301 ve Üzeri Sayfa Arası & 50 & 5,9 \\
\hline Toplam & $\mathbf{8 4 4}$ & $\mathbf{1 0 0}$ \\
\hline
\end{tabular}

Araştırmaya dâhil edilen lisansüstü tezlerin yöntemlerine göre dağılım verileri ile ilgili temel bulgular Tablo 10'da özetlenmiştir. Araştırmaya dâhil edilen lisansüstü tezlerin \%59'unda nicel, \%20,5'inde nitel, \%15,9'unda karma ve \%1,3'ününde literatür taraması yöntemlerinin tercih edildiği belirlenmiştir.

Tablo 10. Lisansüstü Tezlerin Yöntemlerine Göre Dağılımı ile İlgili Genel Bilgiler

\begin{tabular}{ccc}
\hline Yöntemi & Sayı (n) & Yüzde (\%) \\
\hline Nicel & 498 & 59,0 \\
\hline Nitel & 173 & 20,5 \\
\hline Karma & 134 & 15,9 \\
\hline Literatür Taraması & 11 & 1,3 \\
\hline Tez Erişim İzni Yok & 28 & 3,3 \\
\hline Toplam & $\mathbf{8 4 4}$ & $\mathbf{1 0 0}$ \\
\hline
\end{tabular}

Araştırmaya dâhil edilen lisansüstü tezlerin veri toplama yöntemlerine göre dağılım verileri ile ilgili temel bulgular Tablo 11'de özetlenmiştir. Araştırmaya dâhil edilen lisansüstü tezlerin \%57'sinde geleneksel anket, \%11,1'inde görüşme, \%10,9'unda anket ve görüşme, \%4,1'inde gözlem ve görüşme, \%4,1'inde doküman incelemesi ve \%3,6'sında göstergebilim tekniğinden yararlanıldığ tespit edilmiştir (toplam \%90,8). Lisansüstü tezlerin \%09,2'sinde ise online anket, karma anket, odak grup görüşmesi, örnek olay ve anket-doküman incelemesi tekniğinden yararlanılmıştır. 
Aydın ÜNAL, Sinan Baran BAYAR

Türkiye'de Destinasyon Konusunda Yayınlanmış Lisansüstü Tezlerin Bibliyometrik İncelenmesine Yönelik Bir Araştırma

Tablo 11. Lisansüstü Tezlerin Veri Toplama Yöntemlerine Göre Dağılımı ile İlgili Genel Bilgiler

\begin{tabular}{cccccc}
\hline Veri Toplama Yöntemi & $\begin{array}{c}\text { Sayı } \\
(\mathbf{n})\end{array}$ & $\begin{array}{c}\text { Yüzde } \\
(\boldsymbol{\%})\end{array}$ & $\begin{array}{c}\text { Veri Toplama } \\
\text { Yöntemi }\end{array}$ & $\begin{array}{c}\text { Sayı } \\
(\mathbf{n})\end{array}$ & $\begin{array}{c}\text { Yüzde } \\
(\boldsymbol{\%})\end{array}$ \\
\hline Geleneksel Anket & 481 & 57,0 & Odak Grup Görüşmesi & 12 & 1,4 \\
\hline Görüşme & 94 & 11,1 & Anket+Doküman İnc. & 9 & 1,1 \\
\hline Anket+Görüşme & 92 & 10,9 & Online Anket & 6 &, 7 \\
\hline Gözlem+Görüşme & 35 & 4,1 & Örnek Olay & 6 &, 7 \\
\hline Doküman İncelemesi & 35 & 4,1 & Tez Erişim İzni Yok & 29 & 3,4 \\
\hline Göstergebilim & 30 & 3,6 & Toplam & $\mathbf{8 4 4}$ & $\mathbf{1 0 0}$ \\
\hline Karma Anket & 15 & 1,8 & & & \\
\hline
\end{tabular}

Araştırmaya dâhil edilen lisansüstü tezlerin örneklem hacimlerine göre dağılım verileri ile ilgili temel bulgular Tablo 12'de özetlenmiştir. Araştırmaya dâhil edilen lisansüstü tezlerin $\% 49,1$ 'inde 301 ve üzeri, \%25,9'unda 0-50, \%5,3'ünde 251-300, \%4,5'inde 51-100, \%3,9'unda 201-250, \%3,4'ünde 151-200 ve \%3,3'ünde 101-150 örneklem hacmine ulaşıldığı belirlenmiştir.

Tablo 12. Lisansüstü Tezlerin Örneklem Hacimlerine Göre Dağılımı ile İlgili Genel Bilgiler

\begin{tabular}{ccc}
\hline Örneklem Hacmi & Sayı (n) & Yüzde (\%) \\
\hline $0-50$ Örneklem & 219 & 25,9 \\
\hline 51-100 Örneklem & 38 & 4,5 \\
\hline 101-150 Örneklem & 28 & 3,3 \\
\hline 151-200 Örneklem & 29 & 3,4 \\
\hline 201-250 Örneklem & 33 & 3,9 \\
\hline 251-300 Örneklem & 45 & 5,3 \\
\hline 301 ve Üzeri Örneklem & 414 & 49,1 \\
\hline Tez Erişim İzni Yok & 38 & 4,5 \\
\hline Toplam & $\mathbf{8 4 4}$ & $\mathbf{1 0 0}$ \\
\hline
\end{tabular}

Araştırmaya dâhil edilen lisansüstü tezlerin kullanılan kaynak sayısı dağılımlarına göre verileri ile ilgili temel bulgular Tablo 13'te özetlenmiştir. Araştırmaya dâhil edilen lisansüstü tezlerin \%26,4'ünde 101-150, \%20,5'inde 51-100, \%18,6'sinda 151-200, \%9,7'sinde 201-250, $\% 8,6$ 'sında 301 ve üzeri, \%7,3'ünde 251-300 ve \%3,1'inde 0-50 kaynak kullanıldığı tespit edilmiştir.

Tablo 13. Lisansüstü Tezlerin Kullanılan Kaynak Sayılarına Göre Dağılımı ile İlgili

\section{Genel Bilgiler}

\begin{tabular}{ccc}
\hline Kaynak Sayısı & Sayı (n) & Yüzde (\%) \\
\hline 0-50 Kaynak & 26 & 3,1 \\
\hline 51-100 Kaynak & 173 & 20,5 \\
\hline 101-150 Kaynak & 223 & 26,4 \\
\hline 151-200 Kaynak & 157 & 18,6 \\
\hline 201-250 Kaynak & 82 & 9,7 \\
\hline 251-300 Kaynak & 62 & 7,3 \\
\hline 301 ve Üzeri Kaynak & 73 & 8,6 \\
\hline Tez Erişim İzni Yok & 48 & 5,7 \\
\hline Toplam & $\mathbf{8 4 4}$ & $\mathbf{1 0 0}$ \\
\hline
\end{tabular}




\section{Tartışma, Sonuç ve Öneriler}

Çalışmada Yükseköğretim Kurulu Başkanlığı Ulusal Tez Merkezi veri tabanında (YÖKTEZ) 1996-31 Aralık 2019 yılları arasında “destinasyon” konu başlığında yayınlanmış lisansüstü tezlerin (844 adet) bibliyometrik olarak incelenmesi ve belirli başlıklar altında (tezlerin; yıllara göre dağılımı, türü, konusu, danışman unvanları, üniversitesi, enstitüsü, ana bilim dalı, dili, sayfa sayısı, yöntemi, veri toplama yöntemi, örneklemi ve kullanılan kaynak sayıs1) kategorize edilmesi amaçlanmaktadır. Ancak ilgili tezlerin 59 tanesinde erişim izni olmadığından dolayı bazı başlıklar ile ilgili bilgilere ulaşılamamıştır. Bu kapsamda yapılan analizler neticesinde; araştırmaya dâhil edilen "destinasyon" konu başlı̆̆ında lisansüstü tezlerin çoğunluğunun 20102019 yılları arasında yayınlandığı (\%80), 1996-2009 yılları arasında daha az sayıda lisansüstü tez yayınlandığı (\%20) ve 1998-1999 yıllarında ilgili konu başlığında lisansüstü tez çalışması yayınlanmadığı tespit edilememişsir. İlgili konu başlığında yayınlanan lisansüstü tezlerin çoğunluğunun yüksek lisans düzeyinde (\%72); turizm konu başliğında (\%61), profesör unvanlı öğretim üyelerinin danışmanlığında (\%37); Gazi (\%9) ve Akdeniz (\%8) üniversitelerinde; sosyal bilimler enstitülerinde (\%89); turizm işletmeciliği anabilim dalında (\%60); Türkçe dilinde (\%94); 101-200 sayfa aralığında (\%64); nicel yöntemlerle (\%59); geleneksel anket tekniğinden yararlanarak (\%57); 301 ve üzeri sayıda örneklem hacmine ulaşılarak (\%49) ve 101-150 kaynak kullanılarak (\%26) hazırlandıkları belirlenmiştir. Ayrıca ilgili konu başlığındaki lisansüstü tezlerin kısmen de olsa doktora düzeyinde (\%28); iktisadi ve idari bilimler konu başlığında (\%22); doçent (\%35) ve doktor öğretim üyesi (\%28) unvanı taşıyan öğretim üyelerinin danışmanlığında; Dokuz Eylül, Balıkesir ve İstanbul üniversiteleri başta olmak üzere toplamda 95 farklı devlet, özel ve vakıf üniversitesinde; fen-lisansüstü eğitim ve sağlı bilimleri enstitülerinde (\%13); iktisadi ve idari bilimler (\%19) başta olmak üzere 20 farklı anabilim dalında; İngilizce dilinde (\%6); 201 ve üzeri sayfa aralığında (\%36); nitel ve karma yöntemlerle (\%37); görüşme (\%11) başta olmak üzere 11 farklı araştırma tekniği kullanılarak; 0-300 arası örneklem hacmine (\%51) ulaşılarak; 51-100 (\%21), 151-200 (\%19), 201-250 (\%10), 301 ve üzeri (\%9), 251-300 (\%7) ve 0-50 (\%3) arası kaynak kullanılarak hazırlandıkları belirlenmiştir.

$\mathrm{Bu}$ çalışmanın ilgili alanyazına, destinasyon konu başlığında çalışmalar yapan araştırmacılara ve sonraki çalışmalara katkı sağlayacağı öngörülmektedir. Çünkü konu kapsamında yılları itibariyle tüm çalışmaları esas alan ve bu denli kapsamlı inceleyen bir çalışma alanyazında yer almamaktadır. Bu yönüyle çalışma destinasyon konusunda yayınlanmış tezlerin tarihine kapsamlı şekilde 1şık tutmaktadır. Elde edilen bulgular kapsamında destinasyon konu başlığında özellikle 2015 ve sonrasında daha yoğun şekilde (\%63) tezlerin hazırlandığı, ancak tezlerin daha çok yüksek lisans düzeyinde, Türkçe dilinde, nicel yöntemlerle, anket tekniğinden yararlanarak ve ağırlıklı olarak belli üniversitelerde (Gazi, Akdeniz, Dokuz Eylül, İstanbul, 
Çanakkale 18 Mart, Muğla Sıtkı Koçman, Anadolu, vb.) hazırlandıkları belirlenmiştir. Bu durum alanyazında yabancı dillerde, doktora düzeyinde ve farklı veri toplama tekniklerinde çalışmaların kısıtlı olduğunu ortaya koymaktadır. Gelecekteki lisansüstü öğrenim görecek öğrenciler konuyu bu gelişime açı yönleriyle ele alabilirler. Ayrıca sonraki çalışmalarda destinasyon konu başlığında yayımlanmış tezler daha farklı parametreler (başlık, araştırma alanı, en çok danışmanlık vermiş öğretim üyesi, tezlerin hazırlandıkları dillerine göre üniversite dağılımları, yıl temelli tez türleri, vb.) açısından değerlendirilerek ele alınabilir. Ayrıca gelecekteki çalışmalarda turizmin farklı konu başlıklarında yayınlanmış lisansüstü çalışmaların bibliyometrik analizlerinin farklı başlıklar altında incelenmesi turizm alanyazının süreçsel gelişimine 1şık tutacağı düşünülmektedir.

\section{Kaynaklar}

Akmeşe, H., Aras, S. ve Bektaş, F. (2018). Sürdürülebilir turizm konusunda hazırlanan lisansüstü tezlerin incelenmesi. 3. Uluslararast Mesleki ve Teknik Bilimler Kongresi, 21-22 Haziran 2018, Gaziantep, 807-818.

Akyol, C. (2017). Turizm eğitimi konulu lisansüstü tezlerin içerik analizi. IX. Uluslararası Eğitim Araştırmaları Birliği Kongresi, 11-14 Mayıs 2017, Ordu, 796-809.

Al, U., Soydal, İ. ve Yalçın, H. (2010). Bibliyometrik Özellikleri Açısından Bilig'in Değerlendirilmesi. Bilig Dergisi, 55, 1-20.

Alımanoğlu, Ç. A. (2017). Bibliometric Study on Postgraduate Thesis Studies on Rural Tourism in Turkey (2003-2016). Uluslararası Kırsal Turizm ve Kalkınma Dergisi, 1 (1), 6-12.

Alkan, G. (2014). Türkiye'de Muhasebe Alanında Yapılan Lisansüstü Tez Çalışmaları Üzerine Bir Araştırma (1984-2012). Muhasebe ve Finansman Dergisi, 41-52.

Arıca, R. (2014). Seyahat işletmeciliği literatürünün gelişim süreci: Türkiye'de hazırlanan lisansüstü tez çalışmalarının bibliyometrik olarak incelenmesi. VII. Lisansüstü Turizm Öğrencileri Araştırma Kongresi, 4-5 Nisan 2014, Kuşadası, Aydın, 446-462.

Atay, L. (2003). Turistik Destinasyon Pazarlaması ve Bir Alan Araştırması. Yayınlanmamış doktora tezi, Dokuz Eylül Üniversitesi Sosyal Bilimler Enstitüsü, İzmir.

Ayaz, N. ve Türkmen, B. M. (2018). Yöresel Yiyecekleri Konu Alan Lisansüstü Tezlerin Bibliyometrik Analizi. Gastroia: Journal of Gastronomy and Travel Research, 2 (1), 22-38.

Aydın, B. (2014). Yükseköğretim Kurulu Tez Merkezi’nde (Yöktez) Yiyecek İçecek İşletmeciliği Alanında Kayıtlı Bulunan Tezlerin Bibliyometrik Analizi. Disiplinlerarası Akademik Turizm Dergisi, 2 (1), 23-38.

Aydın, B. ve Aksöz, O. E. (2019). Destinasyon Alanında Yayınlanmış Lisansüstü Tezlerin Bibliyometrik Profili. Journal of Tourism and Gastronomy Studies, 7 (1), 615-636.

Beşel, F. (2017). Türkiye'de Maliye Alanında Yapışmış Lisansüstü Tezlerin Bibliyometrik Analizi (20032017). International Journal of Public Finance, 2 (1), 27-62.

Cahit Arf Bilgi Merkezi. (2019). Bibliyometrik çalışma. https://cabim.ulakbim.gov.tr/bibliyometrikanaliz/bibliyometrik-analiz-sikca-sorulan-sorular/ (15.12.2019) 
Crossan, M. M. and Apaydin, M. (2010). A Multi-Dimensional Framework of Organizational Innovation: A Systematic Review of the Literature. Journal of Management Studies, 47 (6), 1154-1191.

Çiçek, D. ve Kozak, N. (2012). Anatolia: Turizm Araştırmaları Dergisi’nde yayımlanan hakem denetimli makalelerin bibliyometrik profili. VI. Lisansüstü Turizm Ö̆̆rencileri Araştırma Kongresi, 12-15 Nisan 2012, Kemer, Antalya, 196-211.

Demirbulat Güdü, Ö. ve Dinç Tetik, N. (2017). Sürdürülebilir Turizm Konulu Lisansüstü Tezlerin Bibliyometrik Profili. Seyahat ve Otel İşletmeciliği Dergisi, 14 (2), 20-30.

Güzeller, C. O. ve Çeliker, N. (2017). Geçmişten Günümüze Gastronomi Bilimi: Bibliyometrik Bir Analiz, Journal of Tourism and Gastronomy Studies, 5 (2), 88-102.

İnce, M., Gül, H. ve Bozyiğit, S. (2017). Türkiye'de Turizm Pazarlaması Konusunda Yazılan Lisansüstü Tezlerin İçerik Analizi Yöntemiyle İncelenmesi: 1990-2016. MANAS Sosyal Araştırmalar Dergisi, 6 (5), 113-130.

Karagöz, D. ve Yüncü, R. H. (2013). Sosyal A ğ Analizi ile Turizm alanında Yazılmış Doktora Tezlerinin Araştırma Konularının İncelenmesi. Adlyaman Üniversitesi Sosyal Bilimler Enstitüsü Dergisi, 6 (15), 205-232.

Karasar, N. (2002). Bilimsel Araştırma Yöntemi (11. Baskı). Ankara: Nobel Yayıncılık.

Kozak, N. (2001). Türkiye'de Turizm Pazarlaması Literatürünün Gelişim Süreci: 1972-1998 Yılları Arasında Hazırlanmış Lisansüstü Tez Çalışmaları Üzerine Biyo-Bibliyografik Bir İnceleme. Anatolia: Turizm Araştırmaları Dergisi, 12, 26-33.

Kulualp Göktaş, H. ve Kalem Yıldırım, M. (2019). Kültür ve Kültürel Farklılıklar Üzerine Yapılan Lisansüstü Tezlere Yönelik Bibliyometrik Bir Analiz. Elektronik Sosyal Bilimler Dergisi, 18 (72), 1970-1985.

Nergiz Güçlü, H. (2014). Türkiye'de lisansüstü turizm tezlerinin bibliyometrik profili (1990-2013). VII. Lisansüstü Turizm Öğrencileri Araştırma Kongresi, 4-5 Nisan 2014, Kuşadası, Aydın, 212-221.

Olalı, H. (1984). Türkiye'de turizm eğitiminin yapısı ve sorunları. Turizm Eğitim Kongresi Tebliğ ve Tartışmalar, Boğaziçi Üniversitesi, İstanbul.

Sanchez, A. D., Del Rio, M. D. and Garcia, A. J. (2017). Bibliometric Analysis of Publications on Wine Tourism in the Databases Scopus and WoS. European Research on Managament and Business Economics, 23 (1), 8-15.

Sünnetçioğlu, A., Yalçınkaya, P., Olcay, M. ve Okan, Ş. (2017). Turizm Alanında Yazılmış Olan Gastronomiye İlişkin Tezlerin Bibliyometrik Profili. Journal of Tourism and Gastronomy Studies, $5(2), 345-354$.

Swarbrooke, J. (1995). The Development \& Management of Visitor Attraction. Oxford: Butterworth Heinemann.

Şahin, E. ve Acun, A. (2015). Turist rehberliği alanınının bibliyometrik profili (makaleler ve lisansüstü tezler). 16. Ulusal turizm Kongresi, 12-15 Kasım 2015, Çanakkale, 1456-1475.

Şahin, E., Akdağ, G., Çakıcı, C. ve Onur, N. (2018). Gastronomi ve Mutfak Sanatları Anabilim Dallarında Yayınlanan Tezlerin Bibliyometrik Analizi. Güncel Turizm Araştırmaları Dergisi, 2 (1), 30-41. 
Aydın ÜNAL, Sinan Baran BAYAR

Türkiye'de Destinasyon Konusunda Yayınlanmış Lisansüstü Tezlerin Bibliyometrik İncelenmesine Yönelik Bir Araştırma

Şardağ, A. (2016). Türkiye'de Coğrafya Alanında Turizm ile İlgili Yapılan Lisansüstü Tezler Üzerine Bir İçerik Analizi. Yayınlanmamış yüksek lisans tezi, Süleyman Demirel Üniversitesi Sosyal Bilimler Enstitüsü, Isparta.

Tayfun, A., Küçükergin, G. F., Aysen, E., Eren, A. ve Özekici, K. Y. (2016). Turizm Alanında Yazılan Lisansüstü Tezlere Yönelik Bibliyometrik Bir Analiz. Gazi Üniversitesi Turizm Fakültesi Dergisi, $1,50-69$.

Tayfun, A., Ülker, M., Gökçe, Y., Tengilimoğlu, E., Sürücü, Ç. ve Durmaz, M. (2018). Turizm Alanında Yiyecek İçecek ile İlgili Lisansüstü Tezlerin Bibliyometrik Analizi. Journal of Tourism and Gastronomy Studies, 6 (2), 523-547.

Tekin, Ö. A. (2016). Türkiye'deki Turizm Tezlerinde Odaklanılan Konular: 1984-2015. Journal of Alanya Faculty of Business, 8 (2), 175-187.

Toksöz, D. ve Birdir, K. (2016). Turizm alanyazında kültürel mirasla ilgili çalışmaların bibliyometrik profili (2006-2015). I. Uluslararası Doğu Akdeniz Turizm Sempozyumu, 22-23 Nisan 2016, Gazimağusa, Kıbrıs, 76-89.

Turan, A. (2014). Turizm konulu yüksek lisans tezlerinin bibliyometrik özellikleri (1983-2003). VII. Lisansüstü Turizm Öğrencileri Araştırma Kongresi, 4-5 Nisan 2014, Kuşadası, Aydın, 3-15.

Üsdiken, B. ve Pasadeos, Y. (1992). Türkiye'de Örgütler ve Yönetim Yazını. Amme İdaresi Dergisi, 25, 107-134.

Yozgat, U. ve Kartaltepe, B. N. (2009). Ulusal Yönetim ve Organizasyon Kongre Kitaplarında Yer Alan Bildirilerin Bibliyometrik Profili: Örgüt Teorisi ve Örgütsel Davranış Bildirileri Üzerine Bir Araştırma. Eskişehir Osmangazi Üniversitesi İ.I.B.F. Dergisi, 4 (1), 149-165.

Yükseköğretim Kurulu Başkanlığı Ulusal Tez Merkezi (YÖKTEZ). (2019). Destinasyon tezleri. https://tez.yok.gov.tr/UlusalTezMerkezi/ (31.12.2019) 